\title{
Housing Consumption of the "Soon-to-Retire" in Hong Kong: A Cross-Sectional Regression Analysis
}

\section{Wadu Mesthrige Jayantha ${ }^{1}$ Lebunu Hewage Udara Willhelm Abeydeera ${ }^{2}$}

RMIT University, Melbourne, Australia.

'The Hong Kong Polytechnic University, Hong Kong.

Email:udaraw.lebunuhewage@connect.polyu.hk

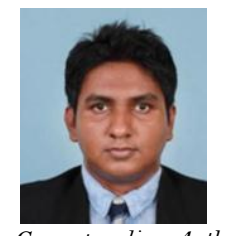

( Corresponding Author)

\begin{abstract}
Availability and quality of housing have long been serious problems in Hong Kong over the years. It is now apparent that the rapidly increasing aging population (those over 65 years) seems to make the housing issue an even more serious one. As the demographic and social structures of the society continue to evolve, government's housing policy should be reviewed and revised from time to time, accordingly, in order to satisfy the changing needs of the society. The main objective of this study is to explore the significant determinants of housing consumption of the 'soon-to-retire' group and suggest an explanation for their underlying dynamics. Based on a sample survey data, a cross-sectional regression model is employed to identify significant determinants that influence housing consumption of this group. Empirical results reveal that housing consumption of this group is influenced not only by market and demographic factors but also by the health status of the household. Heath status of the household, of this age group, is very important as this group is nearing their retirement. The empirical results further reveal that average household size and housing tenure as significant determinants of housing consumption of this study group. By introducing this new factor, we attempt to broaden our knowledge about the housing consumption of this less explored aspect of the housing market.
\end{abstract}

Keywords: Housing consumption, Soon-to-retire, Health status, Housing policy, Hong Kong.

JEL Classification: R21, R31, O18.

Citation | Wadu Mesthrige Jayantha; Lebunu Hewage Udara Willhelm Abeydeera (2019). Housing Consumption of the "Soon-toRetire" in Hong Kong: A Cross-Sectional Regression Analysis. Asian Journal of Economics and Empirical Research, 6(1): 76-84. History:

Received: 4 April 2019

Revised: 14 May 2019

Accepted: 17 June 2019

Published: 15 August 2019

Licensed: This work is licensed under a Creative Commons Attribution 3.0 License (cc)

Publisher: Asian Online Journal Publishing Group
Acknowledgement: Both authors contributed to the conception and design of the study.

Funding: This study received no specific financial support

Competing Interests: The authors declare that they have no conflict of interests.

Transparency: The authors confirm that the manuscript is an honest, accurate, and transparent account of the study was reported; that no vital features of the study have been omitted; and that any discrepancies from the study as planned have been explained.

Ethical: This study follows all ethical practices during writing.

\section{Contents}

1. Introduction

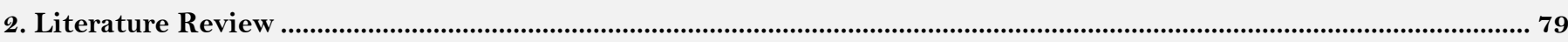

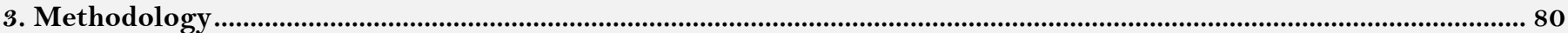

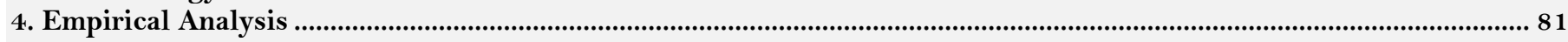

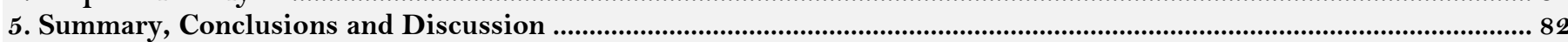

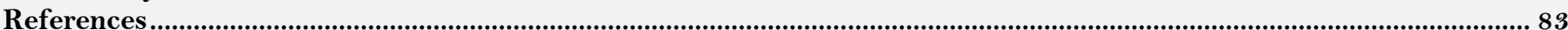




\section{Contribution of this paper to the literature}

The present study adds knowledge to the housing literature in several ways: (a) this is the first comprehensive study in Hong Kong to explore critical determinants of housing consumption behavior of this group; and (b) a new variable, health status (effect of health) was introduced to the housing consumption model.

\section{Introduction}

Availability, adequate size, and quality of housing have long been serious problems in Hong Kong over the years. It is now apparent that the rapidly increasing aging population (those over 65 years) seems to make the housing issue an even more serious one. The proportion of the population in Hong Kong who are aging has continued to grow faster during the last ten years, raising the concerns for the housing of seniors in the community. For instance, the median age of the Hong Kong population rose from $10.1 \%$ in 1996 to $12.4 \%$ in 2006 and further to $15.9 \%$ in 2016 (Census and Statistics Department, 2016). The Authorities forecast the median age continues to rise to 47.7 in 2031 . Most importantly, people aged between 45-64 years old or the 'soon-to-retire' collectively comprised $17.26 \%$ of the total population in $1991,21.8 \%$ in 2001 , and continued to rise to $31.28 \%$ by 2011. It has become the largest age stratum in Hong Kong, with already more than 2.2 million people.

By looking at the population in domestic households living in different types of housing by age in the past decade Table 1, one may notice that number of elderly people (age 65 and above) living in various types of housing (except temporary quarters) has been increasing while public rental housing (PRH) remains the most common type of housing for the elderly. The number of elderly households living in subsidized sale flats has surged in the past decade by $58 \%$ from 95,886 in 2001 to 151,152 in 2011 and 204,985 in 2016. A significant increase (34\%) is also noted in the number of elderly people dwelling in private residential flats from 240,105 in 2001 to 457, 216 in 2016.

The most important phenomenon noticed is that the group of 'soon-to-retire' is taking up a large proportion of the total population in Hong Kong. Unlike the category of aged 65 and above (who are retired and mainly living in $\mathrm{PRH}$ ), a majority of the people in the 'soon-to-retire' ( $42 \%$ of the total age stratum) are living in private residential flats, as they may be more capable to support themselves with private housing. However, when this category of 'soon-to-retire' starts their retirement, their sources of income may not enough to afford private housing anymore (as they may lose housing allowances or other payments). Then they have to rely on other means (like pensions/ Mandatory Provident Fund, investment returns, etc.,) forcing them to change their housing consumption pattern accordingly.

Table-1. Population in Domestic Households by Age and Type of Housing/Quarters, 2001, 2006, 2011 and 2016.

\begin{tabular}{l|l|c|c|c|c}
\hline \multirow{2}{*}{ Age } & Type of Housing/Quarters & \multicolumn{4}{|c}{ Population in Domestic Households } \\
\cline { 3 - 6 } & & $\mathbf{2 0 0 1}$ & $\mathbf{2 0 0 6}$ & $\mathbf{2 0 1 1}$ & $\mathbf{2 0 1 6}$ \\
\hline \multirow{4}{*}{$45-64$} & Public rental housing units & 505434 & 580396 & 646728 & 671,398 \\
\cline { 2 - 6 } & Subsidized sale flats & 235152 & 354575 & 428012 & 414,998 \\
\cline { 2 - 6 } & Private residential flats & 584906 & 732340 & $1,067,211$ & $1,158,791$ \\
\cline { 2 - 6 } & Non-domestic quarters & 3685 & 3484 & 5010 & 7,573 \\
\cline { 2 - 6 } & Temporary quarters & 18205 & 12711 & 14521 & 15,947 \\
\hline \multirow{5}{*}{65 and over } & Public rental housing units & 293971 & 315242 & 331957 & 392,575 \\
\cline { 2 - 6 } & Subsidized sale flats & 95886 & 127193 & 151152 & 204,985 \\
\cline { 2 - 6 } & Private residential flats & 240105 & 275645 & 368,322 & 457,216 \\
\cline { 2 - 6 } & Non-domestic quarters & 1072 & 948 & 1468 & 3,409 \\
\cline { 2 - 6 } & Temporary quarters & 9914 & 6981 & 7784 & 10,740 \\
\hline
\end{tabular}

Source: extracted from Interactive Data Dissemination Service (various years), Census and Statistics Department.

As this group of 'soon-to-retire' takes up the largest proportion of the population of Hong Kong, their housing needs should not be overlooked as the authorities did in the past. People in the age of 45 to 64 comprise the largest age stratum in Hong Kong, and this age group is forecast to increase further in the coming decade Figure 1 (CSD, 2016). The population of this specific group is over 1.2 million Figure 2 that indicates the importance of giving special attention to the need for housing consumption of this group in Hong Kong. When a group of people consists of more than $30 \%$ of the total population, its behaviors and characteristics are worth studying, with the view to implementing better governmental policies. As the demographic and social structures of the society continue to evolve, government's housing policy should be reviewed and revised from time to time, accordingly, in order to satisfy the changing needs of the society. It is thus important and insightful for the government, private property developers and academic scholars to investigate and identify the housing needs of this population group and their underlying determinants in order to prepare a long-term detailed housing strategic plan.

Since the supply of housing has long been a serious issue in Hong Kong; the government is currently under serious criticism about its housing and land supply policy, and the government authorities are being forced to rethink the policies including reinstating the Homeownership Scheme (HOS) in order to ease the current situation. While the authorities focus on the housing policy for the elderly, that is, the immediate need, housing consumption of the 'soon-to-retire' should not be neglected, as this group of people will be the main target user of the senior housing in the near future. Thus, it is high time for authorities to embrace this particular group as an important element in their new housing strategies. A better understanding of the housing consumption of the 'soon-to-retire' is necessary for more effective housing policy for the elderly in the future. As housing issues with high-density dwelling units in Hong Kong is already an extremely serious problem, this issue warrants serious attention by the government, society, and academics. 


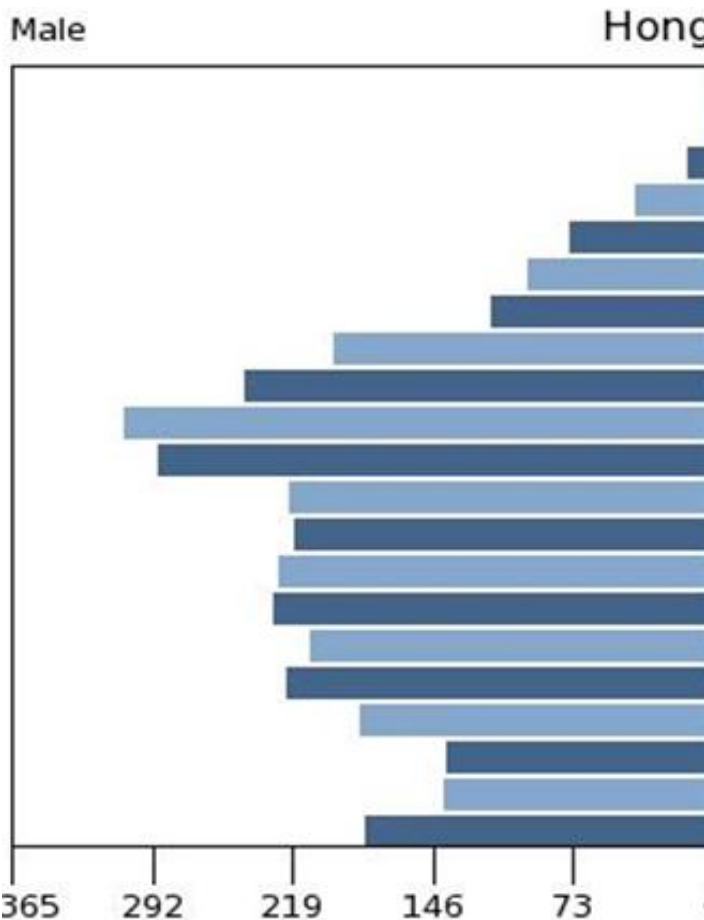

Kong - 2016

Female

Population (in thousands)
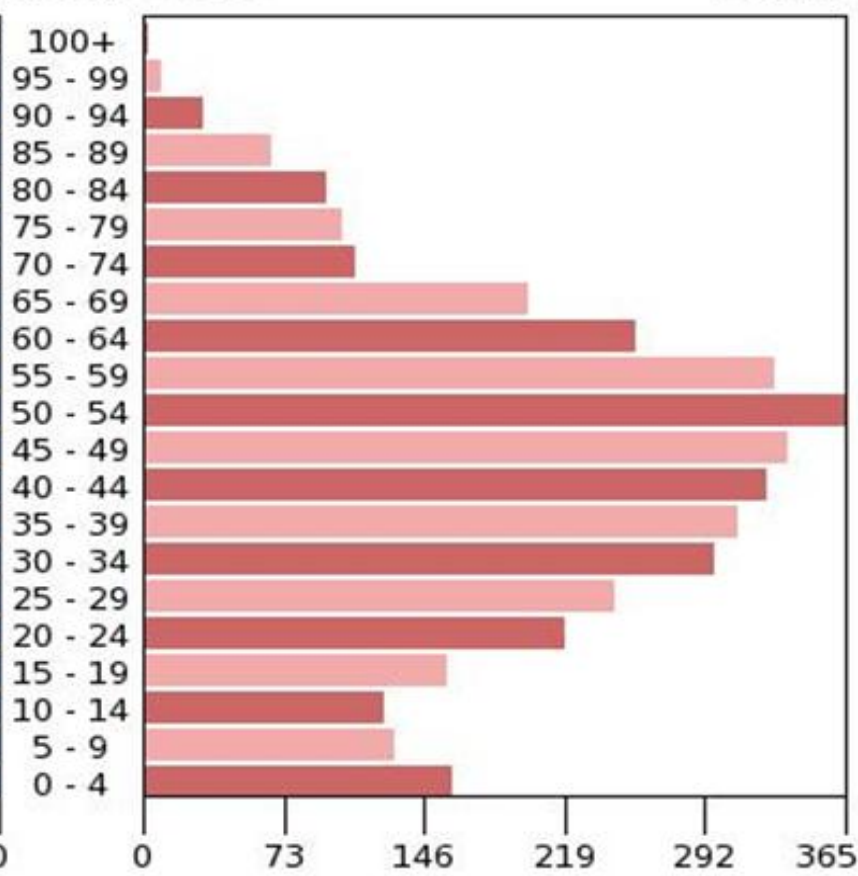

Age Group

Population (in thousands)

Source: CSD (2011).

Figure-1. Population structure of Hong Kong in 2016.

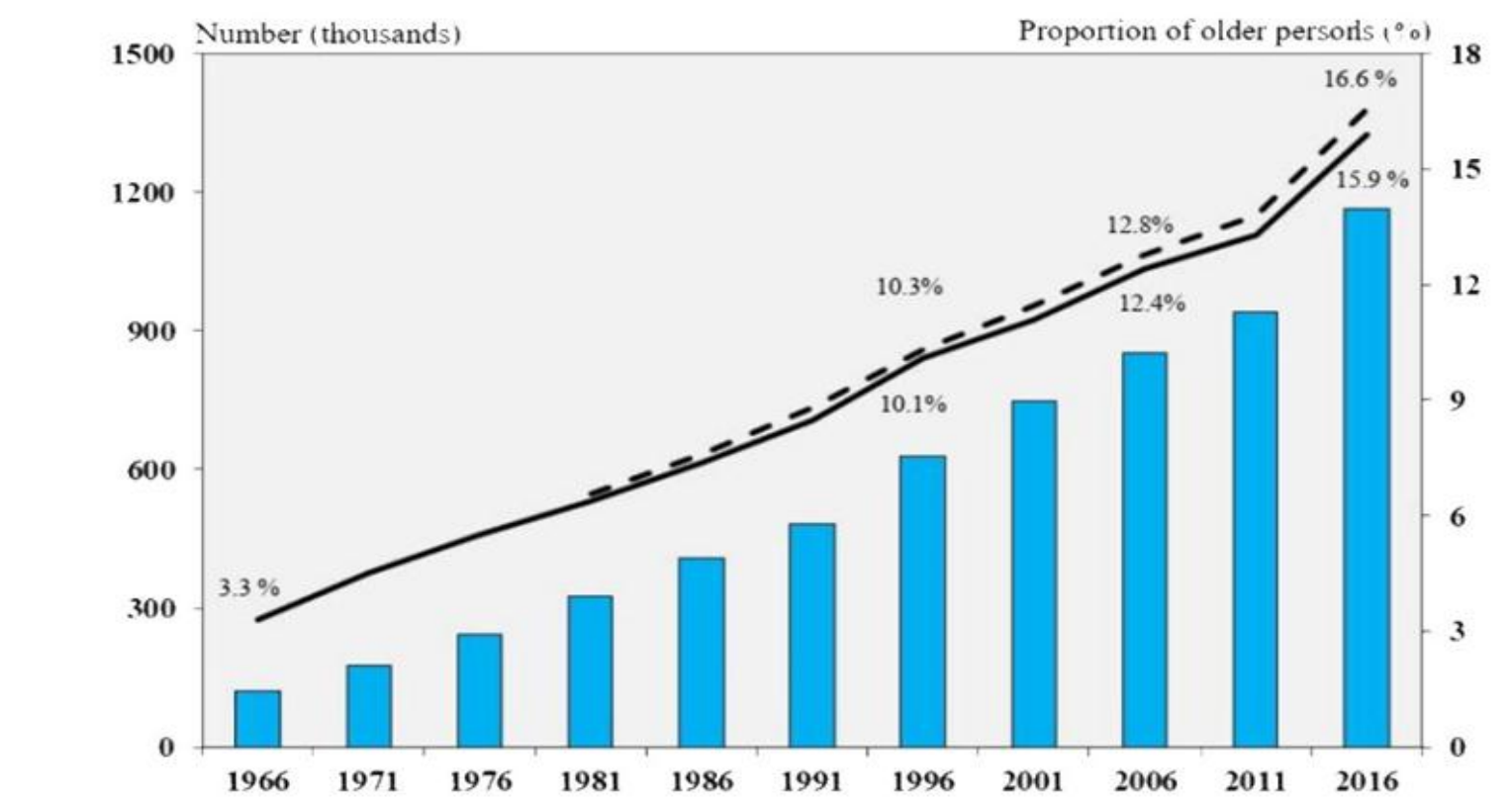

Number of older persons

Proportion of older persons to the total population

- - Proportion of older persons to the total population (excluding foreign domestic helpers)

Source: $\operatorname{CSD}(2011)$.

Figure-2. Population size and growth of the age group 45-64 and over the past 50 years.

Although housing is a serious issue in Hong Kong, research efforts investigating the aging problem in relation to housing consumption in Hong Kong have been quite limited. There are some studies on housing demand of the elderly in the literature (Chiu et al., 2003; Chui and Ko, 2003; Chiu and Ho, 2006; Cheung, 2008; Hui and Yu, 2009) yet comprehensive studies on housing needs and behavior of the 'soon-to-retire' remain limited in Hong Kong. This paper aims to fill this gap in understanding by evaluating the housing consumption of this large group of people who are aged between 45-64 years old.

The main objectives of the present study are (a) to evaluate levels of housing consumption of this soon-toretire group, and (b) to explore significant determinants of housing consumption of this group and suggest an explanation for their underlying dynamics. The study would contribute to the housing literature in several aspects. First, this study is the first of its kind in Hong Kong to evaluate housing consumption behavior and determinants of this group. Second, and most importantly, the health issue (effect of health), which to the authors' knowledge has not been introduced in a comprehensive housing consumption analysis, is to be incorporated into the housing model. The findings of this research will be of special interest to policy-makers and academics in Hong Kong concerned with housing policy planning (e.g. New development area in North East New Territories) and other land and housing policy measures, including housing affordability issues.

The paper is structured as follows. The following section (Section 2) reviews the existing studies in the area of housing consumption, in a particular housing consumption of elderly and the 'soon-to-retire' categories will be 
reviewed, whilst Section 3 provides the theoretical framework for a regression model of the housing demand of the soon-to-retire. Section 4 discusses empirical estimates of the tested model, and the study concludes in Section 5 with a summary and some suggestions for future research.

\section{Literature Review}

There is a significant body of literature on various aspects of housing consumption, including studies in the USA, western countries and elsewhere (e.g. (Bayer and Harper, 2000; Clark and Drever, 2000; Lawler, 2001; Davey, 2006; Boldy et al., 2011; Rioux and Werner, 2011; Basaraba, 2016)). A reasonably rich body of housing studies is also evident recently in China (e.g. (Fu et al., 2000; Li, 2000a;2000b; Huang and Clark, 2002; Huang, 2003a;2003b; Yu, 2004; Chui, 2008)) which is more relevant to Hong Kong.

Different studies view and analyze housing consumption in different perspectives. Their analyses are mainly based on two different approaches, with the first being mainly concerned with economic perspectives that emphasize, largely underlying, market factors. This group argues that households try to maximize housing consumption within a given budget (Silberberg and Suen, 2001; Wong et al., 2012). Many studies (e.g. (Chui, 2001; Davey, 2006; Oswald et al., 2011; Emlet and Moceri, 2012; Chen et al., 2015)) show that factors such as income, wealth, and house prices influence housing consumption behavior significantly.

The second approach mainly emphasizes demographic factors within an economic viewpoint. According to its proponents, demographic characteristics of a family or household influence housing demand significantly. For example, age, family size of households, sex of the household head, and life-cycle events are significant factors (Davey, 2006; Rubin et al., 2009; Lavery, 2015; Tsang, 2016). Thus, household size is positively related to housing consumption (e.g. (Chui, 2001; Leung, 2014)). Wong et al. (2012) also found a positive relationship between age and housing demand. Housing consumption according to them can also be determined by changes in the housing market apart from factors related to characteristics of households (Clark and Dieleman, 2000). Housing consumption is expected to improve over time because of a decline in household size, an increase in the overall housing stock, and the 'trading up' process (Silberberg and Suen, 2001).

The most important factor, which is specifically relevant to the present study, under the demographic characteristics is the life cycle events of a household/person. It is known that households tend to adjust their housing consumption as they experience changes within households and as they progress through the life cycle (Bayer and Harper, 2000; Chen et al., 2015). According to the life-cycle theory, housing consumption varies according to various stages of the life of an individual. People make choices about how much they spend at each of their age as the resources available for them on different stages of their lives varies (Deaton, 2005) and thus their rate of consumption and savings follow a life-cycle pattern (Chen et al., 2015). There are some empirical analyses supporting the life cycle theory. For example, Chui (2001) show there is an increase in the housing demand between the ages of 20 and 30 and a drop of about $1 \%$ per year after the age of 40 .

Under the demographic characteristics, in the literature, health status and the risk of health deterioration of a person have been widely recognized as significant determinants that influence consumption and saving decisions (Finkelstein et al., 2008; Karagiannaki, 2009). Glass and Balfour (2003) concludes that during the working-age, poor health may constrain labor supply, decreasing lifetime earnings and benefits and possibly result in lower total wealth and a lower degree of consumption capacity. Some studies even investigated the impacts of health shocks on housing consumption. Yet, the studies that investigate the relationship between health status and housing consumption of the 'soon-to-retire' remain relatively limited in number.

In a sociological perspective, the relationship between health status and housing selection has long been a controversial issue. Most studies state that there is a causal relationship linking housing conditions and physical and mental disease (Glass and Balfour, 2003). It has been shown that an overcrowded housing environment can lead to poor mental and physical health, while poor social relations at home adversely affect the mental development of children (Menec et al., 2011).

Although there are a significant number of studies available on analyzing the effect of housing environment on health conditions, not many of them evaluate the influence of health status on housing consumption. Thus, this study attempts to address this causal linkage, in particular on a specific age stratum of people. Glass and Balfour (2003) states while the health status of a person can be influenced by the housing condition, it is also possible that people select their housing according to their health status. Moreover, Wolf and Wilmoth (2010) find that health issues are strongly associated with the changes in housing consumption.

By using the classification scheme, Lecovich (2014) uses Brown County, United States as an example and classifies the life cycle of the household into eight stages. The study concludes that there is a substantially strong relationship between changes in the life cycle and housing consumption. It is found that movements along different life-cycle stages lead to characteristic changes in the size and composition of households, and, consequently, in their housing requirements. Lecovich (2014) further explains that when a household progresses to the middle of the life cycle, they will adjust their consumption accordingly. First, they will move to a larger rental unit, then to buy a house. And after reaching the peak (i.e. around Stage 6 and 7) of household size, they begin to reduce their housing consumption by moving to smaller houses or renting smaller units. However, the life-cycle theory does not apply to the choice of household tenure. Some scholars (e.g., (Davey, 2006; Lecovich, 2014; Leung, 2014)) think tenure choices are affected by the changes in socioeconomic status only and not through one's life cycle per se.

In a recent study, using 1996 national survey data, Huang (2003b) analysis of dynamics of housing consumption in urban China after the housing reform concluded that household characteristics had relatively more influence over housing consumption than before. The study further concludes that factors such as life cycle, household income, and city size have had similar effects on housing consumption and residential crowding as in market economies. This shows that changes in the life cycle of a household are important in determining housing consumption. In a more recent study, based on a time series analysis (Blake and Simic, 2005) investigated the housing consumption of the elderly (in their paper, elderly refers to someone 62 years of age or older). They analyzed how housing consumption of the elderly has changed over time and attempted to understand the potential 
housing consumption pattern of this category of households in the future. This study is similar to the present study though the present study is based on a cross-sectional regression analysis.

While there are some studies addressing various aspects of housing consumption in Hong Kong, few focus on a particular age stratum, and none of the group 'soon-to-retire', to the knowledge of the author. This important gap in our understanding - examination of housing consumption of the soon-to-retire in Hong Kong - has not been properly investigated for some reason. In particular, factors affecting housing consumption behavior of this group have not yet been systematically investigated in the housing market.

\section{Methodology}

\subsection{Model and Data Description}

The study is to explore the critical determinants of housing consumption of the 'soon-to-retire' and evaluate whether subjective health concerns will affect housing consumption. As literature shows, theoretically, housing consumption can be explained mainly by two sets of factors: market factors and household demographic characteristics. Though health status, as we observed in the literature, comes under the household characteristics, the present model treats it as a separate category, and thus our model could be specified as:

$$
\mathrm{HC}_{\mathrm{t}}=\alpha+\beta\left(\text { MFact }_{\mathrm{t}}\right)+\pi\left(\mathrm{HHCha}_{\mathrm{t}}\right)+\Omega\left(\text { Hstat }_{\mathrm{t}}\right)+\mu_{\mathrm{t}}
$$

Where HCt is the housing consumption during time period $t$, and MFact, HHCha and Hstat represent market factors, household characteristics, and subjective health status of the target group, respectively. $\alpha$ denotes the intercept term while $\beta, \pi$ and $\Omega$ represent corresponding regression coefficients. Definitions and descriptions of all the variables with data sources are summarized in Table 2 . Housing consumption, which is the dependent variable, in the study is measured by the amount of space per person $\operatorname{SPP}\left(\mathrm{m}^{2}\right)$.

A questionnaire-based sample survey was carried out targeting the soon-to-retire group (who are currently living in private residential flats) during January - March, and June-August 2017, covering a few districts in Hong Kong. The sample of 1200 households was selected randomly from a few private housing schemes in Sham Shui Po, Wong Tai Shin, Tsuen Wan, and North Point, which reasonably covers the entire territory, and thus avoids any bias of the sample. The profile of age and marital status of the respondents in the sample survey carried out are shown in Table 3. The questionnaire basically comprised three sections, with the first section aiming at background information of the respondents such as age, gender, marital status and educational level and so on. In the next part, detailed household characteristics including household size, housing size, type of housing and household income were included, while the last part aims at exploring personal opinions on housing consumption after retirement and the impacts of health status changes on housing consumption.

\begin{tabular}{|c|c|c|c|}
\hline Category & Variables & Descriptions & Source of Data \\
\hline \multicolumn{4}{|l|}{ Dependent Variable } \\
\hline & Space Per Person (SPP) & $\begin{array}{l}\text { Amount of average living space (in terms } \\
\text { of square feet) consumed by each person } \\
\text { in a household }\end{array}$ & Questionnaire Survey \\
\hline \multicolumn{4}{|c|}{ Independent Variables } \\
\hline \multirow[t]{3}{*}{ Market Factors } & Housing Price (HP) & $\begin{array}{l}\text { Unit housing price at the time of the } \\
\text { survey }\end{array}$ & Questionnaire Survey \\
\hline & Household Income (HI) & Amount of household income, monthly & Questionnaire Survey \\
\hline & Household Size (AHS) & $\begin{array}{l}\text { The average number of people in a } \\
\text { household }\end{array}$ & Questionnaire Survey \\
\hline \multirow[t]{3}{*}{$\begin{array}{l}\text { Household } \\
\text { Characteristics }\end{array}$} & Housing Size (Hsize) & $\begin{array}{l}\text { Size of the living unit occupied by the } \\
\text { household }\end{array}$ & Questionnaire Survey \\
\hline & $\begin{array}{l}\text { Housing Ownership } \\
\text { (HO) }\end{array}$ & $\begin{array}{l}\text { Whether the respondent is living in a } \\
\text { self-owned flat or rental flat }\end{array}$ & Questionnaire Survey \\
\hline & Education Level (EDU) & $\begin{array}{l}\text { Education Background and attainment of } \\
\text { the study subject }\end{array}$ & Questionnaire Survey \\
\hline $\begin{array}{l}\text { Individual Health } \\
\text { Concern }\end{array}$ & $\begin{array}{l}\text { Subjective Health } \\
\text { Status (SHS) }\end{array}$ & Individual self-rated health status & Questionnaire Survey \\
\hline
\end{tabular}

Among the completed questionnaires collected, only 1088 of them were used for the analysis as 112 sets of questionnaires were discarded due to their incompleteness. Most of the discarded questionnaires were because the respondents were unwilling to disclose their household income or were unaware of the housing size of their living units.

\begin{tabular}{c|c|c|c}
\multicolumn{4}{c}{ Table-3. Percentage Distributions of Total Respondents by Age and Sex. } \\
\hline Age & $\mathbf{\%}$ & $\mathbf{S e x}$ & $\mathbf{\%}$ \\
\hline $45-49$ & 41 & Male & 44 \\
\hline $50-54$ & 27 & Female & 56 \\
\hline $55-59$ & 15.5 & & \\
\hline $60-64$ & 16.5 & & \\
\hline
\end{tabular}

\subsection{Variable Description}

A cross-sectional regression analysis was carried out to explore significant determinants of housing consumption of the soon-to-retire group. The dependent variable of the model of this study is the housing consumption of the respondents of the survey, and it is measured in term of space per person (SPP), which is computed by dividing the total gross floor area of the unit by the number of persons in a household. 
Housing consumption is measured in various ways in the literature. In market economies, with the assumption of competitive equilibrium, housing expenditure is often used as a measure of housing consumption (Menec et al., 2011). Housing consumption can be measured by the amount of living floor space occupied by one person, or space per person (Jayantha and Lau, 2008; Jayantha and Hui, 2012) or the number of rooms per person (The MetLife, 2010; Wolf and Wilmoth, 2010). Holding other factors constant, when the household size expands, the space per person or rooms per person will decline. Housing consumption in the present study is also measured in terms of floor space per person.

The model uses three different sets of independent variables: market, demographic and health status in its empirical analysis. Theoretically, it is expected that housing prices (HP) negatively link with housing consumption, whilst household income (HY) is expected to have a positive relationship with space consumption. The study thus hypothesizes that higher the property price the smaller the amount of space consumption and vice versa, and on the other hand the higher the household income, the more actual floor space the household occupies.

The study also hypothesizes a negative relationship between housing consumption and household size. It is expected that as average household size (AHS) increases, space consumption per person declines, while the size of the house remains unchanged. Average housing size (Hsize) is another important variable that affects floor space consumption per person. In the study, it is measured in terms of Gross Floor Area (GFA). It is not difficult to comprehend that the larger the housing size, the greater the space consumption per person, and vice versa, ceteris paribus. It is noted in the literature that housing consumption per person is relatively larger in owner-occupied houses and less crowded than rental housing (Huang and Clark, 2002). According to their study, floor space per person for owner-occupied flats is 23.35 square meters, whilst it is 14.03 square meters per person for rental apartments. In this view, housing ownership is expected to be positively related to housing consumption. In this model, HO is a dummy variable which amounts to " 1 " if the respondent owns the living property and "O" if otherwise.

Education Level (EDU) is another important variable that can influence space consumption level and pattern of an individual. It is known that as a person attains higher levels of education; he/she may have a relatively stronger will and affordability to pursue better living and higher housing consumption. Therefore, it is hypothesized that there is a positive relationship between education level (EDU) and housing consumption. Last, but not least, Subjective Health Status (SHS), which is the most important element in this study, is a significant factor that can influence housing consumption of an individual. This factor has not been properly addressed in the literature. As Karagiannaki (2009) states, people with poor health status are very likely to face financial hardships with lower income and wealth and spend less compared to people with good health conditions. Housing as a durable consumer good, in this study, it is assumed that health condition and housing consumption are positively related: i.e., poor health condition with lower consumption and vice versa.

\section{Empirical Analysis \\ 4.1. Descriptive Analysis}

Average housing consumption in Hong Kong has been quite low compared to many other cities. The median housing consumption (average floor area per person) of the soon-to-retire category is found to be 155 square feet Table 4. This figure is in line with the previous findings. For example, according to Hui et al. (2004) and Planning Department (1999) it was found 151 square feet (14 square meters). This slight difference is due to the fact that those two studies focus on average population whilst the present study is on the 'soon-to-retire' category, which is more capable and willing to consume more space for living than the general population. This, however, gives an idea of housing consumption and residential crowding in Hong Kong.

Table-4. Descriptive statistics of variables

\begin{tabular}{c|c|c|c|c}
\hline Variable & Mean & $\boldsymbol{\sigma}$ & Min. & Max. \\
\hline SPP & 154.90 & 82.83 & 64 & 600 \\
\hline HP & 9847.97 & 13663.21 & 4000 & 16250 \\
\hline HI & 39735.14 & 22194.79 & 8000 & 140000 \\
\hline AHS & 3.87 & 1.29 & 1 & 6 \\
\hline Hsize & 543.45 & 231.94 & 220 & 1500 \\
\hline HO & 0.56 & 0.49 & 0 & 1 \\
\hline EDU & 5.21 & 0.78 & 1 & 3 \\
\hline SHS & 3.02 & 1.23 & 1 & 5 \\
\hline
\end{tabular}

\subsection{Statistical Interpretation in the Model}

Standard statistical techniques including the $t$-test, $F$-test and adjusted $R^{2}$ are used to interpret the results of the regression model. All the parameters of the model will be tested using $t$-test by comparing the empirical $t$-value with the critical $t$-value. If the absolute $t$-statistic for a particular parameter is greater than the critical value, it means that particular variable is significant. The overall significance of the model, on the other hand, is tested by using the $F$-test in the model. The overall significance of a model is said to be good when the empirical $F$-value is larger than the critical value. Finally, the explanatory power of the model is reflected through the adjusted $R^{2}$ value, with the value of it ranges from 0 to 1 : higher the value the better the model.

\subsection{Regression Results}

The results of the regression model including explanatory power and goodness-of-fit measures are reported in Table 5. All the coefficients are of the anticipated sign and are statistically highly significant at conventional levels (except two variables). Demographic factors seem to have influenced housing consumption significantly. Among the variables, AHS, HO and SHS seem to have a significant impact on housing consumption. For example, AHS (coefficients: -56.22) and HO (coefficients: 0.26) seem to be the most influential, indicating that housing 
consumption in Hong Kong is influenced significantly by demographic factors. This finding is in line with some previous research findings in Hong Kong (e.g., Jayantha and Hui (2012)). As for the homeownership variable (HO), the estimated coefficient of 0.26 indicates that homeowners exert a significant effect on floor space consumption per person. This supports our theoretical hypothesis that housing consumption per person in owner-occupied housing is higher compared to renters. Owners are in a better position to consume larger housing and are less likely to experience residential crowding.

Table-5. Regression results of the model.

\begin{tabular}{|c|c|c|c|}
\hline Independent Variable & Coefficient & $t$-statistic & $p$-value \\
\hline Constant & 170.4300 & 8.6930 & 0.0000 \\
\hline$H P$ & -0.0000 & -0.5730 & 0.5670 \\
\hline$H I$ & $0.0010^{* * * *}$ & 3.6860 & 0.0000 \\
\hline AHS & $-56.2280^{* * * *}$ & -17.5580 & 0.0000 \\
\hline $\mathrm{HO}$ & 0.2600* *** & 13.2670 & 0.0000 \\
\hline Hsize & 3.2910 & 0.5360 & 0.5930 \\
\hline$E D U$ & $8.5730^{*} *$ & 1.7620 & 0.0800 \\
\hline SHS & 6.9760* **** & 2.5490 & 0.0120 \\
\hline $\begin{array}{c}\text { Adjusted R-squared } \\
\text { F-statistic }\end{array}$ & $\begin{array}{c}0.7730 \\
90.2760\end{array}$ & & \\
\hline Prob (F-statistic) & 0.0000 & & \\
\hline
\end{tabular}

The variable EDU is also found to be significant while carrying the expected sign, which implies higher education is linked with higher housing consumption. In general, it is expected household income to increase as a person attains higher education as higher education leads to one having a relatively highly paid employment. Chances of getting hired are relatively high when someone is more educated and very likely to earn more, which will certainly lead to a better living standard.

As expected, HI, as a market factor, stimulates housing consumption significantly. It was found that HI is highly significant (at 99 percent significance) and carries the expected positive sign, even though the degree of a coefficient is relatively smaller. This indicates that households with greater income have a greater chance of using a larger amount of space per person as they can afford a larger housing unit. This finding is supported by some previous studies (e.g., (Luffman, 2006; Oswald et al., 2011; Jayantha and Hui, 2012)). The empirical estimate suggests that a 1 percent rise in household income leads to a 0.1 percent increase in housing consumption per person. As the housing market in Hong Kong is dominated by the market forces, it is expected household income plays an important role in floor space consumption.

However, it is extremely surprising that the estimated coefficient of housing price (HP) is found to be insignificant even though it carries the expected negative sign. This is perhaps partly due to the fact that housing price in Hong Kong is subject to changes in many national and global scenarios and is, therefore, less controllable. The public sector intervention in the housing market might have also affected HP in the private housing market. This finding is however consistent with some previous findings. For example, Jayantha and Lau (2008) found that housing prices have only a moderate influence on the supply of new housing in Hong Kong, whilst Luffman (2006) reveals that changes in housing price influence the home-ownership in the short-run, but not in the long-run.

The most important variable introduced into the model is the health status (SHS) of the household. To the knowledge of the authors, this is the first time health concern was introduced into a housing consumption model. Importantly it was found to be highly significant, and also carrying the anticipated sign. The positive sign of the SHS variable implies that the health status of an individual is positively related to housing affordability and consumption of that person. This finding is consistent with some research findings of the urban sociology researchers in their field of research. For example, health status and the risk of health deterioration of a person were recognized as an important factor that can influence consumption and saving decisions (Finkelstein et al., 2008; Karagiannaki, 2009). Lecovich (2014) also states that it is possible people chose their housing according to health status, whilst Wolf and Wilmoth (2010) mention that health stocks are strongly associated with the changes in housing consumption. However, the present study is one of the earliest formal studies that evaluate the influence of health status on housing consumption in Hong Kong, though there are some studies available on analyzing the effect of housing environment on health conditions in the housing literature.

In summary, housing consumption of this age group is determined by a combination of market and demographic factors. Most importantly, this study reveals an important finding: housing consumption is positively influenced by the health status of the household in this soon-to-retire age stratum.

\section{Summary, Conclusions and Discussion}

Using a cross-sectional regression model, the main objective of this study is to explore significant determinants of housing consumption of the 'soon-to-retire' group, and suggest an explanation for their underlying dynamics. Empirical results reveal that average household size and housing tenure as significant determinants of housing consumption of this age group. Results suggest that larger households are more likely to experience residential crowding and under consumption. In fact, overcrowding has been a serious issue in Hong Kong over the last few decades. More than one family living in one housing unit is not uncommon in Hong Kong (see Tang (2008)). With several households sharing a small unit, overcrowding is even much more evident in private housing units (Ho and Wong, 2009). Housing floor space consumption by many households in Hong Kong is much lower than they needed, with a very low space per consumption level compared to developed countries. Findings of all these studies support the finding of our study that household size plays an important role in floor space consumption per person.

The empirical analysis also suggests that better-off households (households with larger income) and households who own their housing units tend to consume larger space per person with less residential crowding. 
This is an expected phenomenon, which is in line with findings of previous studies (e.g., (Luffman, 2006; Oswald et al., 2011; Jayantha and Hui, 2012)). However, housing price was found to be insignificant which is quite surprising. This finding, however, is also consistent with some previous findings (e.g., (Perez et al., 2001; Jayantha and Lau, 2008)).

In the study, we found that housing consumption of this group is influenced not only by market and demographic factors but also by the health status of the household. Health status of the household, in particular of this age group is very important as this group is nearing their retirement. Soon after they begin their retirement, not only may they not receive the previous amount of income (from the employment), but also they have to spend a considerable amount of their income on health matters, which will severely hinder the strength of housing affordability and amount of consumption.

The present study adds knowledge to the housing literature in several ways: (a) this is the first comprehensive study in Hong Kong to explore critical determinants of housing consumption behavior of this group; (b) most importantly, a new variable, health issue (effect of health) was introduced to the housing consumption model, and to the authors' knowledge this variable has not been introduced in a comprehensive housing consumption analysis in the housing literature, in particular in this age stratum. By introducing this new factor, we attempt to broaden our knowledge about the housing consumption of this less explored aspect of the housing market.

The findings of this study trigger some important implications. Overall, the findings of this study will be of interest to scholars and policy-makers in Hong Kong concerned with housing issues and other housing policyrelated measures including housing affordability issues. For policymakers, the results of this paper may shed light on the necessity of housing policies that can better cope with the needs of this large group of housing users in the future. The housing consumption pattern of this group is a little different from the existing elderly. For example, floor space usage per person of this group is a little higher than the rest of the households in general, which indicates "soon-to-retire" has a stronger will and ability to consume more. As this group of people, which take up a large proportion of the total population in Hong Kong, private property developers, as well as government authorities, may need to take a note of their preference in order to better understand their housing needs in the future. Findings of this study thus may also help to further refine housing policy and other policies related to the housing issue.

\section{References}

Basaraba, S., 2016. What does aging in place mean for older adults? Available from https://www.verywell.com/what-does-aging-in-placemean-for-older-adults-2223464 [Accessed 18 May 2016].

Bayer, A.H. and L. Harper, 2000. Fixing to stay: A national survey of housing and home modification issues. Washington DC: AA RP.

Blake, K.S. and A. Simic, 2005. Elderly housing consumption: Historical patterns and projected trends. U.S. Department of Housing and Urban Development., ISA RC 39, USA.

Boldy, D., L. Grenade, G. Lewin, E. Karol and E. Burton, 2011. Older people's decision regarding 'ageing in place': A Western Australian case study. Australasian Journal on Ageing, 30(3): 136-142.Available at: https://doi.org/10.1111/j.1741-66 12.2010.00469.x.

Census and Statistics Department, 2016. Interactive data dissemination service. HKSAR Government.

Chen, X., H. Yang and W. Zhang, 2015. A comprehensive sensitivity study of major passive design parameters for the public rental housing development in Hong Kong. Energy, 93: 1804-1818.Available at: https://doi.org/10.1016/j.energy.2015.10.061.

Cheung, S.K., 2008. A study of future demand for elderly housing in Hong Kong. MSc. Dissertation, The University of Hong Kong, Hong Kong.

Chiu, R., M. Ho, G. Siu, D. Cheung and C. Chan, 2003. Projection of housing needs and demands of the elderly. In: Comprehensive study on the housing needs of the elderly in Hong Kong. Hong Kong Housing Society and The University of Hong Kong. pp: 77-92.

Chiu, R.L. and M.H. Ho, 2006. Estimation of elderly housing demand in an Asian city: Methodological issues and policy implications. Habitat International, 30(4): 965-980.

Chui, E., 2001. Doomed elderly people in a booming city: Urban redevelopment and housing problems of elderly people in Hong Kong. Housing, Theory and Society, 18(3-4): 158-166.Available at: https://doi.org/10.1080/14036090152770528.

Chui, E., 2008. Challenges and opportunities in a capitalist Chinese City. Ageing International, 32(3): 167-182.Available at: https://doi.org/10.1007/s12126-008-9015-2.

Chui, E. and L. Ko, 2003. Review of government policies on housing care and services for the elderly. In Comprehensive study on the housing needs of the elderly in Hong Kong. Hong Kong Housing Society and the University of Hong Kong, Hong Kong. pp: 3863.

Clark, W.A. and A.I. Drever, 2000. Residential mobility in a constrained housing market: Implications for ethnic populations in Germany. Environment and Planning A, 32(5): 833-846.Available at: https://doi.org/10.1068/a3222.

Clark, W.A.V. and F.M. Dieleman, 2000. Households and housing: Choices and outcomes in the housing market. New Brunswick: Cen ter for Urban Policy Research, Rutgers University.

CSD, 2011.2011 population census: Graphic guide. Hong Kong: HKSAR Government Logistics Department.

Davey, J., 2006. Ageing in place: The views of older homeowners on maintenance, renovation and adaptation. Social Policy Journal of New Zealand, 27(1): 128-141

Deaton, A., 2005. Franco Modigliani and the life cycle theory of consumption. Banca Nazionale Del Lavoro Quarterly Review, 58: 9 1-107.

Emlet, C.A. and J.T. Moceri, 2012. The importance of social connectedness in building age-friendly communities. Journal of Aging Research.Available at: https://doi.org/10.1155/2012/173247.

Finkelstein, A., E.F. Luttmer and M.J. Notowidigdo, 2008. What good is wealth without health? The effect of health on the marginal utility of consumption. Journal of the European Economic Association, 11(1): 22 1-258.

Fu, Y., K.T. David and N. Zhou, 2000. Housing choice behavior of urban workers in China's transition to a housing market. Journal of Urban Economics, 47(1): 61-87.Available at: https://doi.org/10.1006/juec.1999.2133.

Glass, T.A. and J.L. Balfour, 2003. Neighborhoods, aging, and functional limitations. In I. Kawachi, \& L. F. Berkman (Eds.). Neighborhoods and health. Oxford: OUP. pp: 303-334.

Ho, L.S. and G.W.-C. Wong, 2009. The first step on the housing ladder: A natural experiment in Hong Kong. Journal of Housing Economics, 18(1): 59-67.Available at: https://doi.org/10.1016/j.jhe.2009.02.003.

Huang, Y., 2003a. A room of one's own: Housing consumption and residential crowding in transitional urban China. Environment and Planning A, 35: 591-614.

Huang, Y., 2003b. Renters' housing behavior in transitional urban China. Housing Studies, 18(1): 103-126.

Huang, Y. and W.A. Clark, 2002. Housing tenure choice in transitional urban China: A multilevel analysis. Urban Studies, 39(1): 732.Available at: https://doi.org/10.1080/00420980220099041.

Hui, E.C.M., M. Lam and V. Ho, 2004. Land use policy and patterns in Hong Kong. ENHK Conference Proceedings 2004, Cambridge, 2-6 July.

Hui, E.C.M. and K.H. Yu, 2009. Residential mobility and aging population in Hong Kong. Habitat International, 33(1): 10-14.

Jayantha, M.W. and C.-M.E. Hui, 2012. Housing consumption and residential crowding in Hong Kong: A long-term analysis. Journal of Facilities Management, 10(2): 150-172.Available at: https://doi.org/10.1108/14725961211218785. 
Jayantha, M.W. and S.S.Y. Lau, 2008. Floor space per person and housing development: An urban growth approach to estimate hou sing supply in Hong Kong. Urban Policy and Research, 26(2): 177-195.Available at: https://doi.org/10.1080/08111140801986509.

Karagiannaki, E., 2009. The effect of health on consumption decisions in later life: Evidence from the UK. London: London School of Economics and Political Science.

Lavery, A., 2015. Aging in place: Perceptions of older adults on low income housing waitlists. A PhD Dissertation Submitted to the Faculty of the Graduate School of Social Work, University of Denver.

Lawler, K., 2001. Aging in place: Coordinating housing and health care provisions for America's growing elderly population. Washington DC: Joint Centre for Housing Studies.

Lecovich, E., 2014. Ageing in place: From theory to practice. Anthropological Notebooks, 20(1): 21-33.

Leung, C.J., 2014. An evaluation of the quality of public rental housing provided to the elderly in Hong Kong. Hong Kong SAR: University of Hong Kong.

Li, S., 2000a. Housing consumption in urban China: A comparative study of Beijing and Guangzhou. Environment and Planning A, 32(6): $1115-1134$.

Li, S., 200ob. The housing market and tenure decision in Chinese cities: A multivariate analysis of the case of Guangzhou. Housing Studies, $15(2): 213-236$.

Luffman, J., 2006. Measuring housing affordability perspectives. Statistics Canada. pp: 16-25.

Menec, V.H., R. Means, N. Keating, G. Parkhurst and J. Eales, 2011. Conceptualizing age-friendly communities. Canadian Journal on Aging, 30(3): 479-493.

Oswald, F., D. Jopp, C. Rott and H.W. Wahl, 2011. Is aging in place a resource for or risk to life satisfaction? The Gerontologist, $51(2): 238-$ 250.Available at: https://doi.org/10.1093/geront/gnq096.

Perez, F.R., G.F.-M. Fernandez, E.P. Rivera and J.M.R. Abuin, 2001. Ageing in place: Predictors of the residential satisfaction of elderly. Social Indicators Research, 54(2): 173-208.

Planning Department, 1999. The survey of housing aspirations of households (Executive Summary). Hong Kong: Hong Kong Government Printer.

Rioux, L. and C. Werner, 2011. Residential satisfaction among aging people living in place. Journal of Environmental Psychology, $31(2)$ : 158-169.Available at: https://doi.org/10.1016/j.jenvp.2010.12.001.

Rubin, L., J. Renkema, S. Downie and R. Romer, 2009. Naturally occurring retirement communities and neighborhood villages. Office of Legislative Oversight (Report Number 2009-11).

Silberberg, E. and W. Suen, 2001 . The structure of economics, a mathematical analysis. Boston, USA: McGraw-Hill.

Tang, W.-S., 2008. Hong Kong under Chinese sovereignty: Social development and a land (re) development regime. Eurasian Geography and Economics, 49(3): 341-361.Available at: https://doi.org/10.2747/1539-72 16.49.3.341.

The MetLife, 2010. Aging in place 2.0 - rethinking solutions to the home care challenge. New York, USA: Met Life.

Tsang, E., 2016. Hong Kong urged to think of ways to fund long-term elderly care. Available from http://www.scmp.com/news/hongkong/health-environment/article/2054276/hong-kong-urged-think-ways-fund-long-term-elderly.

Wolf, D.A. and J.M. Wilmoth, 2010. Housing consumption in late life: The role of income, health shocks, and marital shocks. Center for Retirement Research at Boston College, Chestnut Hill, MA.

Wong, F., E. Hui, K.W. Chung, T. Li and E. Lui, 2012. Housing for the elderly in Hong Kong - affordability and preferences, The Hong Kong Polytechnic University, Hong Kong. Available from https://www.hkis.org.hk/ufiles/Elderly-FinalReport.pdf [Accessed 28 September 2017].

Yu, Z., 2004. Heterogeneity and dynamics in China's emerging urban housing market: Two sides of success story from the late 1990 s. Habitat International, 30(2): 277-304.Available at: https://doi.org/10.1016/j.habitatint.2004.02.010. 